\author{
MASA: Journal of History \\ Vol. 1, No. 2, Desember 2019
}

\title{
AWAL KEHIDUPAN MASYARAKAT TRANSMIGRASI DI RASAU JAYA 1
}

\author{
Muhammad Arif \\ Pendidikan Sejarah IKIP PGRI Pontianak \\ Email: arif200199@gmail.com
}

\begin{abstract}
Abstrak
Tujuan penelitian ini adalah untuk mengetahui sejarah datangnya transmigrasi di Desa Rasau Jaya 1, cara masyarakat trasmigran beradaptasi dengan masyarakat dengan penduduk asli di Desa Rasau Jaya 1, Kabupaten Kubu Raya, Kalimantan Barat. dan kehidupan sosial ekonomi dan budaya masyarakat transmigrasi serta perubahan sistem pertanian Desa Rasau Jaya 1. Penelitian ini menggunakan metode sejarah yang terdiri dari empat langkah yaitu Heuristik, kritik sumber, interpretasi dan historiografi. Dalam penelitian ini dapat disimpulkan bahwa untuk meratakan penyebaran penduduk di Indonesia dari daerah yang padat penduduk namun luas wilayahnya kecil ke wilayah yang besar namun jumlah penduduknya masih sedikit. Pada awal kedatangannya mereka harus menyesuaikan diri dengan lingkungan yang ada di Kalimantan khususnya pada bidang pertanian. Hal ini dikarenakan perbedaan jenis tanah yang ada dan cara sistem pertanian. Jika di Jawa mereka menggunakan sistem irigasi namun saat berada di daerah transmigrasi mereka menggunakan sistem pasang surut. Setelah beberapa waktu mereka dapat saling berbaur dengan masyarakat asli dan salin bertukar pikiran mengenai teknik bercocok tanam yang baik sesuai dengan tanah gambut yang ada di Rasau Jaya 1. Kehidupan mereka lebih sejahtera di tanah rantau karena mereka mampu menyekolahkan anak-anaknya hingga ke perguruan tinggi. Mata pencarian mereka pun di dominasi pada sektor pertanian dan pertenakan. Selain itu mereka membawa banyak budaya Jawa dan adat istiadat di Rasau Jaya seperti adat lahiran, pernikahan dan juga kematian.
\end{abstract}

Kata kunci: transmigrasi; adaptasi; Rasau Jaya;

\begin{abstract}
The purpose of this research is to find out the history of transmigration in the village of Rasau Jaya 1, the homesteader community efforts to adapt to the natives of the village of Rasau Jaya 1, and the social, economic, and cultural communities in the village homestader Rasau Jaya 1, Kubu Raya West Kalimantan come to 1972-1979. This research uses the historical method which consists of four steps namely heuristics, source criticism, interpretation and historiography. In this study, transmigrant program is to evenly spread the spread of Indonesia's population from areas that the densely populated but its territory is small to large areas but its population is small. At the beginning of their arrival they have to adjust to the environment In Wets Kalimantan, epecially in agriculture. This is due to differences in the types of soil that exist and how to grow crops. If carried out they grow crops using an irrigation system but while in the transmigration area they use a tidal system. After some time they can mingle with the natives and exchange ideas about good farming techniques in accordance with peat soils in the village of Rasau Jaya 1. Their lives are more prosperous in overseas land they are able to send their children to collage. Their livelihood was dominated by the agriculture and livestock sectors. Besides that they bring a lot of Javanese culture and customs in Rasau Jaya such as birth customs, marriage, and also death.
\end{abstract}

Keywords: transmigration; adaptation; Rasau Jaya; 


\section{PENDAHULUAN}

Rasau Jaya sebelumnya merupakan bagian dari Desa Punggur sebelum terpecah atau memekarkan daerahnya sendiri dari Kecamatan Sungai Kakap. Kemudian pada tahun 1970-an dibuka lahan untuk para Transmigran yang didatangkan dari Pulau Jawa oleh pemerintah Indonesia untuk meratakan penyebaran penduduk dipulau Kalimantan. Kecamatan Rasau Jaya sendiri terdiri atas 7 Desa yang terdiri dari enam desa program Transmigrasi dan 1 Desa setempat yang didiami oleh penduduk asli. Adapun desa yang dikembangkan dalam program Transmigrasi ini yaitu: Desa Rasau Jaya I, Desa Rasau Jaya II, Desa Rasau Jaya III, Desa Bintang Mas, Desa Pematang Tujuh dan Desa Sungai Bulan. Sedangkan Desa yang didiami oleh penduduk asli yaitu Desa Rasau Jaya Umum.

Pemukiman Transmigrasi di Desa Rasau Jaya 1 merupakan program Transmigrasi yang ditanggung oleh pemerintah. Dengan adanya program Transmigrasi di Desa Rasau Jaya 1, Desa ini memiliki kemajuan yang cukup besar antara lain bertambahnya jumlah penduduk, semakin padatnya pemukiman atau rumah penduduk, dan Jalan utama yang sudah berupa aspal dimana sebelumnya masih berupa tanah yang apabila banjir akan menjadi becek. Dengan masuknya program Transmigran di Desa Rasau Jaya 1 memunculkan berbagai budaya yang dibawa oleh masing-masing kelompok Transmigran dari Pulau Jawa. Salah satu budaya yang berkembang seiring dengan masuknya Program Transmigrasi yaitu Kesenian Kuda Lumping, pencak silat serta Wayang Kulit.

Permasalahan pendudukan di Indonesia tidak hanya cepat lajunya pertumbuhan tetapi juga penyebaran yang tidak merata. Menanggapi masalah ini, maka Pemerintah telah menyelenggarakan program Transmigrasi. Program Transmigrasi bertujuan untuk menyeimbangkan penyebaran penduduk melalui pemindahan penduduk dari wilayah yang padat penduduknya ke wilayah yang jarang penduduk, tetapi memiliki kerangka yang lebih luas dalam kerangka Pembangunan Nasional. 


\section{METODE}

Metode Penelitian yang digunakan dalam penelitian ini adalah metode penelitian Historis. Metode penelitian Historis adalah prosedur pemecahan masalah dengan menggunakan data masa lalu atau peninggalan-peninggalan baik untuk memahami kejadian atau suatu keadaan yang berlangsung pada masa lalu terlepas dari masa sekarang dalam hubungannya dengan suatu kejadian atau masa lalu, selanjutnya kerap kali juga hasilnya dapat digunakan untuk meramaikan kejadian atau suatu keadaan masa yang akan dating (Sayuti, 1989: 32). Dalam Metode Penelitian Historis memiliki empat tahapan yang akan dilakukan dalam penulisan Sejarah. Tahapan tersebut antara lain:

\section{Heuristik}

Heuristik merupakan Tahapan pertama dalam pengumpulan data atau sumber, baik sumber primer maupun sumber sekunder. Sumber dokumen dalam penelitian ini dapat diperoleh berdasarkan jenis sumber apapun, baik yang bersifat lisan, tulisan, gambar atau benda-benda arkeologi. Dalam penelitian ini sumber dokumentasi antara lain: Daftar nama-nama penduduk Transmigran di Rasau Jaya 1, Peta wilayah rasau jaya serta dokumentasi beberapa bangunan yang ada sejak awal kedatangan Transmigrasi, wawancara dengan tokoh yang sezaman dengan peristiwa masa lampau tersebut. Baik tokoh langsung, masyarakat sekitar yang terlibat didalam peristiwa tersebut.

\section{Kritik Sumber}

Kritik Sumber Sejarah adalah upaya untuk mendapatkan otentitas dan kredibilitas. Kritik Ekstern yaitu usaha mendapatkan otentisitas sumber dengan melakukan penelitian fisik terhadap sumber tersebut. Kritik Intern adalah kritik yang berdasarkan pada kredibilitas sumber, artinya isi informasi dokumen tersebut benar-benar dapat dipercaya, tidak dimanipulasi.

\section{Interpretasi}

Pada tahap ini peneliti melakukan penafsiran terhadap data-data yang telah didapatkan selanjutnya peneliti berusaha untuk melakukan analisis data atau melakukan pembentukan dan generalisasi sejarah.

\section{Historiografi}


Pada tahap akhir ini peneliti melakukan penyusunan suatu fakta-fakta yang didapat dilapangan kemudian dirangkai menjadi suatu cerita sejarah yang disusun secara kronologis atau beruntun antara peristiwa yang satu dengan peristiwa yang lainnya dan ditulis secara ilmiah.

\section{HASIL DAN PEMBAHASAN}

\section{Kondisi Geografis Rasau Jaya}

Rasau Jaya sebelumnya merupakan bagian dari Desa Punggur sebelum terpecah dari kecamatan Sungai Kakap yang masih berupa wilayah Rukun Warga (RW). Yang kemudian pada tahun 1969-1970-an dibuka lahan untuk para transmigrasi yang didatangkan dari Pulau Jawa. Kecamatan Rasau Jaya terdiri dari 7 Desa yang terdiri dari 6 Desa program transmigrasi dan 1 Desa setempat yaitu desa yang didiami masyarakat asli. Untuk desa yang dikembangkan melalui program Transmigrasi yaitu: Desa Rasau Jaya I, Desa Rasau Jaya II, Desa Rasau Jaya III, Desa Bintang Mas, Desa Pematang Tujuh, dan Desa Sungai Bulan.

Desa Rasau Jaya I merupakan kawasan transmigrasi yang berhasil menjadi pusat pertumbuhan dan Ibukota Kcematan. Desa Rasau Jaya I telah menjadi pusat sentral kehidupan para transmigran diseluruh Kecamatan Rasau Jaya yaitu dengan berdirinya bangunan pemerintahan, bangunan sekolah, pasar, pertokoan, bengkel, dan juga Instansi yang berkaitan dengan jasa seperti Kantor Pos, Bank Kalbar, Sorum Motor dan juga Terminal speed boat serta pelabuhan.

Pemukiman Transmigrasi di Desa Rasau Jaya 1 merupakan program Transmigrasi yang ditanggung oleh pemerintah. Dengan adanya program Transmigrasi di Desa Rasau Jaya 1, Desa ini memiliki kemajuan yang cukup besar antara lain bertambahnya jumlah penduduk, semakin padatnya pemukiman atau rumah penduduk, dan Jalan utama yang sudah berupa aspal dimana sebelumnya masih berupa tanah yang apabila banjir akan menjadi becek. Dengan masuknya program Transmigran di Desa Rasau Jaya 1 memunculkan berbagai budaya yang dibawa oleh masing-masing kelompok Transmigran dari Pulau Jawa. Salah satu budaya yang berkembang seiring dengan masuknya Program Transmigrasi yaitu Kesenian Kuda Lumping, pencak silat serta Wayang Kulit. 
Permasalahan pendudukan di Indonesia tidak hanya cepat lajunya pertumbuhan tetapi juga penyebaran yang tidak merata. Menanggapi masalah ini, maka Pemerintah telah menyelenggarakan program Transmigrasi. Program Transmigrasi bertujuan untuk menyeimbangkan penyebaran penduduk melalui pemindahan penduduk dari wilayah yang padat penduduknya ke wilayah yang jarang penduduk, tetapi memiliki kerangka yang lebih luas dalam kerangka Pembangunan Nasional.

\section{Kedatangan Transmigran di Desa Rasau Jaya 1}

Sebelum masuk ke Rasau Jaya para transmigran terlebih dulu ditempatkan di Batulayang lebih tepatnya di Balai Transmigrasi Batulayang. Karena pada saat itu untuk pembukaan lahan juga masih belum selesai. Sehingga pada awal kedatangan masyarakat transmigran keadaan rasau jaya masih dikelilingi hutan belantara, belum terdapat persawahan. Untuk mendapatkan jaduk atau jatah beras dari ditempatkannya transmigran sampai ke dinas transmigrasi setengah hari baaru sampai. Jika difikir tidak sampai $2 \mathrm{~km}$ jaraknya hanya untuk mendapatkan beras. Hal tersebut dikarenakan kondisi jalan yang rusak sehingga susah untuk diakses. Masyarakat banyak mengeluh akan hal itu. Namun untuk masalah keamanan dan makan tidak ada kekurangan. Masyarakat Transmigran yang datang ke Rasau Jaya 1 berasal dari beberapa daerah di Jawa Timur, Jawa tengah, dan Yogyakarta.

Untuk masyarakat transmigran dari jawatimur terbagi 3 angkatan yaitu pertama dari Bojonegoro, Malang. Kedua, berasal dari Madiun, Ponorogo. Ketiga, berasal dari Jember dan Surabaya. Sementara dari Jawa Tengah dan Yogyakarta berasal dari Banyumas, Kebumen, Purwodadi, dan Bantul. Untuk fasilitas yang diterima para transmigran saat pertama datang yaitu yang utama rumah kemudian jaduk (makanan), untuk jaduk sendiri sudah komplit seperti ikan asin, beras, bumbu-bumbu dll serta bibit-bibit tanaman. Pada saat itu atap rumah hanya terbuat dari atap sehingga saat hujan seringkali bocor. Sementara untuk dinding rumah hanya menggunakan triplek. Sehingga, masyarakat masih sering menumpang dirumah-rumah warga yang tidak bocor. Sebenarnya untuk tanah mereka mendapat jatah dari pemerintah seluas 2 ha untuk masing-masing Kepala 
Keluarga (KK) yang terdiri dari lahan pekarangan 0,25 ha, lahan usaha I 0,75 ha, dan lahan usaha II 1 ha. Lahan pekarangan adalah hamparan yang berada disekitar rumah tinggal warga transmigran, sedangkan lahan usaha adalah lahan yang harus digarap sebagai modal untuk melakukan usaha tani sebagai mata pencarian yang tetap. Lahan usaha 1 penyerahannya bersamaan dengan lahan pekarangan yaitu lokasi pada saat transmigran tiba dilokasi, sedangkan lahan usaha II penyerahannya dilakukan kemudian.

\section{Upaya Masyarakat Transmigran Beradaptasi Dengan Penduduk Asli}

Tantangan yang harus dipecahkan saat berada ditempat yang baru adalah proses adaptasi. Adaptasi merupakan proses belajar untuk bisa menyesuaikan diri pada lingkungan yang baru. Proses adaptasi yang dilakukan oleh para transmigran di lingkungan barunya dilakukan secara bertahap yaitu adaptasi dengan lingkungan alam dan dengan penduduk asli. Pada lingkungan alam di Desa Rasau Jaya 1 yang merupakan hutan gambut dan rawa-rawa menjadikan para transmigran harus kuat bertahan hidup dari lingkungan yang masih banyak nyamuk malaria dan binatang-binatang liar seperti ular dan babi. Suhu cuaca di Kalimantan Barat yang panas karena dilalui garis Khatulistiwa. Sarana transportasi yang hanya bisa dilalui jalur air untuk menuju Kota Pontianak.

Proses adaptasi

Diwilayah yang baru ini, masyarakat transmigran Jawa harus menyesuaikan keadaan lingkungan alam yang jauh berbeda dengan keadaan atau struktur tanah yang ada dijawa. Kondisi tanah atau lahan pulau Kalimantan pada umumnya adalah gambut, begitu juga lahan yang berada di Kecamatan Rasau Jaya. Kondisi lahan bergambut memerlukan cara pengolahan tersendiri agar dapat ditanami padi. Para petani Rasau Jaya mempunyai pola pasang surut sedangkan para transmigran terbiasa dengan pola irigasi. Dengan kondisi tersebut maka para transmigran harus menyesuaikan diri dengan lingkungannya. Untuk itu, mereka diberikan pelatihan agar mampu mengolah lahan gambut dengan baik. Disamping itu, masyarakat transmigran harus beradaptasi dengan lahan usahanya. 
Awal bercocok tanam transmigran harus membersihkan sisa-sisa potongan kayu dari bekas membabat hutan dan tidak terlepas juga dari serangan babi hutan. Tetapi sekitar tahun 1976-1977 hama babi sudah musnah dengan pembasmian obat dan pemburuan. Dalam bercocok tanam antara masyarakat transmigran dengan penduduk asli saling berkomunikasi mengenai jenis cocok tanam, teknik bercocok tanam dan harga komoditi di pasaran. Tahun 1972 proses adaptasi sudah terjalin cukup erat. Adaptasi yang dilakukan adalah adanya asimilasi, kesenian dan cara bercocok tanam. Para transmigran yang awalnya tidak kuat menjalani kehidupan ditempat baru yang masih serba terbatas, lama kelamaan dengan kesabaran para transmigran dapat bertahan hidup ditempat transmigrasi sampai saat ini.

Adapun bibit padi disediakan oleh pemerintah, segala kebutuhan masyarakat transmigran dipenuhi atau dibiayai oleh pemerintah mulai dari jatah hidup, bibit padi, peralatan pertanian, sampai masalah kesehatan. Namun, disisi lain mereka masih menemui kesulitan untuk beradaptasi dengan alam dan juga terkait kondisi kesehatan karena pada saat itu banyak penyakit yang menyerang masyarakat transmigran karena kondisi saat itu masih belum memadai untuk hidup layak. Setelah lahan dibersihkan dari semak-semak dan kayu, langkah yang dilakukan berikutnya adalah membuat penyemaian bibit dengan cara membuat wadah atau tempat yang didalamnya diberi lumpur ataupun tanah yang diberikan pupuk. Kemudian setelah beberapa hari bibit disebarkan dan kemudian ditutup dengan tanah kembali dan ditutup dengan dedaunan biasanya masyarakat menggunakan daun alang-alang. Hal ini dilakukan untuk menghindari bibit dirusak oleh burung. Setelah kurang lebih dua minggu (14 hari) bibit biasanya sudah mulai muncul ke permukaan tanah dan ditunggu beberapa minggu lagi untuk selanjutnya bibit siap ditanam.

Untuk sistem pengairan sawah, mereka menggunakan sistem pengairan yang dilakukan masyarakat asli di Rasau Jaya yaitu dengan sistem parit. Mereka membuat parit-parit kecil disekitar sawah yang dihubungkan ke saluran sekunder selanjutnya saluran sekunder tersebut menghubungkan ke sungai. Manfaat dari saka atau handil adalah dapat menampung air yang berlebihan dari lahan sawah, 
kemudian menghantarkannya ke sungai. Para petani trans tidak hanya belajar bertanam padi disawah pasang surut, tetapi juga bertanam kelapa dan juga Palawija. Selain kebutuhan bahan pokok beras, petani trans juga pada saat itu menanam sayur-sayuran untuk kebutuhan hidup sehari-hari. Sementara untuk bahan lainnya seperti gula dan garam mereka mendapat bantuan dari pemerintah.

\section{Kehidupan Sosial, Ekonomi dan Budaya Masyarakat Transmigran Rasau Jaya 1}

\section{Interaksi Sosial}

Sukidi memberikan gambaran mengenai hubungan interaksi sosial masyarakat Transmigran. Setelah tiba di lokasi trans, kebanyakan para transmigran tidak siap dengan kondisi alam yang jauh berbeda dengan kondisi di Jawa. Dengan begitu, mau tidak mau mereka harus beradaptasi dengan lingkungan dan berinteraksi dengan masyarakat setempat. Mereka harus bekerja keras membuka lahan dengan peralatan yang sederhana, dengan gambut yang begitu tebal. Belum lagi gigitan binatang hutan yang bisa membahayakan keselamatan mereka. Itu semua mau tidak mau harus dihadapi para transmigran yang ada di Rasau Jaya. Mereka yang mau bekerja keras dan tidak putus asa akhirnya berhasil. Namun mereka yang kurang ulet dan mudah menyerah akhirnya memutuskan untuk meniggalkan lokasi dan hidup ditempat lain. Proses interaksi masyarakat transmigran biasanya terjadi di tempat-tempat umum seperti pasar dan ladang atau sawah. Hal ini disebabkan lokasi pemukiman mereka terpisah dan saling berjauhan.

Pada awalnya proses interaksi sulit dilkukan karena perbedaan bahasa yang mana penduduk asli menggunakan bahasa melayu sedangkan masyarakat transmigran menggunakan bahasa Jawa. Lambat laun mereka pun saling memahami dan pada saat itulah proses interaksi berjalan dengan baik. Masyarakat asli sendiri banyak membantu masyarakat transmigran dalam menyesuaikan diri dengan kebiasaan mereka seperti menampung air hujan untuk minum, menghadapi berbagai jenis binantang yang mereka temui, mengolah makanan yang ditemukan dihutan dan lain-lain. Ia pun mengatakan selain kegiatan gotong 
royong masyarakat juga terlibat dalam berbagai kegiatan olahraga yang meliputi sepakbola, bola voli dan tenis meja. Ia menambahkan, kegiatan olahraga tersebut dapat membuat masyarakat akrab satu sama lain. Adapula berbagai kegiatan keagamaan yang dilakukan guna menjalin kebersamaan seperti Maulid Nabi SAW, Isra' Mi'raj dan sebagainya. Hal tersebut sama dengan yang diungkapkan oleh Waras bahwa untuk menjalin kebersamaan antara penduduk asli dan masyarakat transmigran sering dilaksanakan kegiatan keagamaan seperti yasinan, pengajian dan tahlilan.

\section{Kehidupan Ekonomi}

Sukidi mengatakan bahwa ia terdorong untuk mengikuti program transmigrasi karena hanya mendapat sedikit tanah dipulau jawa. Walaupun hanya sebagai petani ia sangat bersyukur hidupnya menjadi lebih baik saat ini. Selain sebagai petani, sukidi juga bekerja sambilan seperti memelihara sapi dan buruh bangunan untuk menambah kebutuhan hidupnya sehari-hari.

Sementara mengenai pertanian persawahan, petani transmigran menanam padi sekali dalam satu tahun, namun ada juga yang menanam sampai dua kali dalam setahun. Selain lahan pertanian yang diolah untuk menanam padi masyarakat transmigran juga menanam jagung manis, pisang, dan kelapa serta masih banyak lainnya. Rasau Jaya juga dikenal sebagai penghasil jagung manis, jagung manis yang dihasilkan oleh masyarakat bahkan dijual sampai ke Kota Pontianak. Dari berbagai hasil pertanian yang beraneka ragam tersebut kehidupan para transmigran dapat menjadi jauh lebih baik dan sejahtera.

Dalam menunjang sektor ekonomi, pemerintah telah menempatkan penyuluh pertanian, perkebunan dan peternakan masing-masing satu petugas di Desa Rasau Jaya 1. Masyarakat petani di Desa Rasau Jaya 1 berinisiatif membentuk kelompok-kelompok tani. Kegiatan dari keloompok tani antara lain mengelolah tanah dan menanaminya dengan tanaman umur pendek, mendengarkan siaran radio dan menggelar penyuluhan pertanian. Selain pertanian dan perkebunan ada lagi sektor peternakan yang diusahakan oleh para transmigran. Ada dua sistem yang berlaku berkenaan dengan peternakan ini 
sistem ini di istilahkan dengan sapi gaduhan dari dinas peternakan dan sapi gaduhan dari dinas transmigrasi. Perbedaanya adalah sapi gaduhan dari dinas peternakan digaduh selamat 4 tahun dan selama itu wajib menyerahkan perkembangbiakannya kepada pemerintah sebanyak dua ekor anak sapi berumur minimal 1 tahun, baru setelah itu induk resmi dijadikan hak milik peternak. Sementara sapi gaduhan transmigrasi digaduh selama dua tahun, bila si induk sudah berkembang biak manghasilkan anak berumur 8 bulan maka induk diserahkan kepada pemerintah dan anak sapi tersebut menjadi milik si peternak.

Sektor pertanian, baik itu bercocok tanam atau beternak pada dasarnya merupakan mata pencarian para transmigran, tetapi seiring pertumbuhan ekonomi berkembang banyak diantara mereka yang kemudian beralih profesi menjadi pedagang, karyawan pabrik, pegawai negeri maupun pekerja jual jasa lainnya. Secara garis besar dapat dikatakan bahwa transmigrasi yang dilakukan di Desa Rasau Jaya 1 telah berhasil mengangkat perekonomian para transmigrasi.

\section{Kehidupan Budaya}

Selain dibidang sosial dan ekonomi, masyarakat juga berinteraksi dalam bidang budaya. Masyarakat trans mempunyai budaya yang berbeda, namun mereka mencoba untuk menyesuaikan dengan budaya yang ada di tempat mereka. Sukidi mengatakan bahwa penduduk Jawa membawa kebiasaan hidup mereka sehari-hari, seperti bahasa, adat, dan selamatan ritual hidup, mulai dari perkawinan, kelahiran, sampai kematian. Setiap tahun menjelang Ramadhan biasanya diselenggarakan selamatan megengan yaitu, selamatan yang biasanya dilakukan di rumah pemimpin rukun tetangga ataupu dimasjid-masjid setempat dengan setiap rumah membawa makanan berupa nasi, lauk pauk kemudian ketika sudah berkumpul, semua makanan bagikan kepada masyarakat yang hadir pada saat itu. Tradisi ini berlangsung sehari sebelum puasa atau pada saat hari pertama melaksanakan sholat Tarawih.

Untuk upacara kelahiran yang dibawa masyarakat jawa di daerah transmigrasi seperti acara Tingkeban (Upacara Mandi Ibu Hamil 7 Bulan). Selamatan dimulai sejak bayi dalam kandungan saat kehamilan ibu menginjak 
tujuh bulan yang disebut tingkeban. Tingkeban sendiri dilakukan dengan membacakan doa-doa yang biasanya dilakukan oleh dukun bayi. Peralatan yang diperlukan seperti nasi gurih lengkap dengan ayam panggang utuh yang tidak dipotong, nasi serondeng kelapa, urap dan sayur lodeh, jajan pasar atau sebagainya. Acara selanjutnya sang ibu mandi kembang setaman, yang terdiri dari bunga melati, kenanga, mawar merah dan putih, serta cempaka. Sang ibu berganti kain sebanyak tujuh kali dan sang ayah membelah dua cengkir. Tujuan tingkeban ini sendiri bagi masyarakat jawa adalah untuk mendidik sang bayi agar menjadi manusia yang berbudi luhur, tidak suka berkelahi, dan menjadi anak yang patuh. Namun untuk saat ini upacara tingkeban mengalami perubahan dengan adanya pengaruh islam. Tingkeban tidak lagi menggunakan doa-doa yang dilakukan dukun bayi tetapi dengan doa-doa islam yang dilakukan oleh ustadz. Pasangan suami istri juga diberi nasihat seperti yang ada didalam al-quran.

Tradisi selannjutnya yaitu melahirkan, saat melahirkan seorang bayi bersama tembuni (ari-ari) dan tali pusar akan dikeluarkan dari rahim sang ibu. Sesuai dengan adat jawa, ari-ari dan pusat diberi perlakuan istimewa karena dianggap sebagai penghubung antara sang bayi dan sang ibupada saat didalam rahim. Tali pusar dan ari-ari dicuci menggunakan air bersih, kemudian dimasukkan kedalam kendi yang terbuat dari tanah liat dan diberi rempah-rempah seperti kunit, bawang, garam, kertas, pensil, dan rautan. Hal ini bertujuan agar sang bayi nantinya menjadi orang yang pandai dan mempunyai kepribadian yang menyenangkan. Kendil tersebut setelah dilakukan prosesi dengan mencuci tali pusar dan ari-ari kendil tersebut ditanam didalam tanah setelah didoakan oleh dukun beranak atau dukun bayi yang ada pada saat itu lalu diberi teplok atau lampu minyak tanah dan sekelilingnya dipagari agar tidak dimakan binantang. Maksud dan tujuan tradisi ini adalah agar empat saudara bayi yang lahir berurutan (kawah atau ketuban, tali pusar, ari-ari, dan darah) tidak mengganggu kehidupan sang bayi selama berada didunia.

Setelah acara melahirkan dilanjutkan dengan Selamatan Brokohan, selamatan bayi yang baru lahir dilakukan pada malam hari. Bahan yang perlu disiapkan adalah bubur merah-putih, nasi urap dengan lauk-pauk, serta jenang 
monco warno. Tujuan dari brokohan sendiri adalahuntuk menyedekahi orang yang melahirkan serta bidan atau dukun yang membantu proses persalinan agar mendapat berkah, selamat, panjang umur dan juga barokah.

Bagian terakhir adalah Pasaran (Upacara memberi nama), Pemberian nama sang bayi ketika sang bayi sudah berumur lima hari, walaupun pemilihan nama sudah dilakukan sebelum sang bayi dilahirkan. Kegiatan ini dimulai ketika para tamu sudah hadir semua, acar dimulai dengan permainan hadrah dan lagu-lagu islami. Selanjutnya sang ayah dan ibu sambil membawa bayi dihadapan para pemuka agama pada saat itu dengan melantunkan ayat-ayat al-quran. Setelah selesai pemuka agama mengucapkan basmallah dan memberikan nama yang sudah disiapkan oleh orang tua, lalu mengusap bayi dengan membacakan niat sebanyak dua kali. Rangkaian acara dilakukan dengan menggunting rambut sang bayi dan mengolesinya dengan tepung tawar yang telah disiapkan oleh ulama dan telah dibacakan doa-doa.

Terdapat perbedaan yang cukup kelihatan dalam upacara tradisi pasaran ini apabila dibandingkan dengan dan upacara pasaran yang ada di Jawa. Pasaran yang terjadi di Rasau Jaya sudah mengadopsi tradisi potong rambut di masyarakat asli yang ada di Rasau Jaya yaitu masyarakat melayu. Adanya pembacaan ayatayat suci dan lantunan musik hadrah menunjukan ciri-ciri budaya melayu. Untuk acara adat kelahirannya sendiri masih menggunakan tradisi Jawa. Pelaksanaan adat dan tradisi ini biasanya disesuaikan dengan kondisi masing-masing para transmigran terutama kondisi ekonomi mereka pada saat awal terjadinya program transmigrasi.

Tradisi selanjutnya yang dibawa masyarakat transmigran ke daerah barunya yaitu upacara perkawinan. Dalam adat Jawa, umumnya urutan-urutan proses menuju perkawinan ternagi menjadi dalam lima tahap. Tahap pertama adalah perkenalan dengan keluarga kemudian melamar. Saat melamar biasanya juga membicarakan kelanjutan hubungan antara kedua belah pihak sekaligus mempersiapkan tanggal pernikahan. Tahap kedua adalah meneguhkan kembali atau memantapkan kembali hubungan yang lebih dalam. Tahap ini terbagi menjadi tiga acara. 
Pertama, acara srah-srahan yang intinya menyerahkan barang-barang antaran sesuai lambang ikatan terhadap kedua calon pengantin. Barang tersebut meliputi cincin emas, seperangkat pakaian wanita, buah-buahan, makanan tradisional, daun sirih, dan uang. Kedua Peningset yaitu dengan bertukar cincin emas antara kedua calon pengantin. Ketiga, gedhok dino artinya memantapkan kembali tanggal pernikahan beserta persiapan-persiapan yang anntinya dibutuhkan. Tahap ketiga adalah tahap persiapan secara matang yang didalamnya berisi tentang menyusun siapa-siapa yang akan diundang, pertemuan antara keluarga, kerabat, dan tetangga yang akan membantu kelancaran pelaksanaan acara perkawinan, dan calon mempelai melapor ke KUA tempat diselenggarakannya acara sekaligus mengundang penghulu untuk hadir dalam upacara ijab kabul. Tahap keempat adalah rangkaian rangkaian upacara dan acara untuk pernikahan. Pada tahap ini mulai dilakukan pasang tarub dan tratag (hiasan janur atau daun kelapa muda sebagai tanda akan ada pernikahan), kembar mayang (batang pisang, janur, nanas, daun kemuning, dan bambu dapur), pasang tuwuhan (terdiri dari janur, daun kluwih, daun beringin dan rantingnya, daun dadap serep, seuntai padi, cengkir gading, setandan pisang raja, tebu wulung, kembang dan padi, serta kembang setaman), siraman (mandi-mandi), dan midodareni (malam sebelum pernikahan). Tahap kelima merupakan tahap terakhir dalam prosesi pernikahan adat Jawa adalah ijab kabul (sumpah pernikahan) dan acara panggih pengantin.

Panggih adalah acara yang berisi liron kembar mayang (tukar menukar kembar mayang), gantal (melempar sirih), ngidhak endhog (menginjak telur), pengantin wanita membasuh kaki pengantin pria, minum air degan (kelapa muda), dan dikepyok dengan bunga warna warni. Setelah acara panggih selesai, pengantin melakukan timbangan (duduk dipangku oleh orang tua mempelai perempuan), kacar-kucur, dan dulangan (suap-suapan). Kemudian prosesi terakhir adalah sungkeman yaitu memohon doa restu dari orang tua dan kaum tua yang berisi anggota keluarga agar kehidupan mereka langgeng. Setelah semua selesai maka selanjutnya acara resepsi dengan adat Jawa. Dalam proses panggih, pengantin laki-laki harus keluar terlebih dahulu dari rumah pengantin perempuan, 
kemudian rombongan pihak laki-laki berjalan menuju tempat resepsi pengantin dan disana sudah menunggu pengantin wanita. Dengan iringan langgam jawa kebo giro, pengantin laki-laki berjalan menuju tempat pengantin wanita dan kemudian saling melempar sirih.

Kemudian adat terakhir yaitu adat kematian. Terdapat beberapa adat tradisi yang dibawa masyarakat Jawa di Rasau Jaya yaitu, nelung dino (tiga hari), mitung dino (tujuh hari), matang puluh dino (empat puluh hari), nyatus dino (seratus hari), mendak sepisan (setahun), dan nyewu (seribu hari). Acara ini dilakukan pada malam hari yaitu dengan melalui pengajian yang didalamnya dilantunkan Surah Yasin, tahlilan, doa kubur, dan lain0-lain intinya mendoakan agar yang meninggal mendapat kan tempat yang layak disisi Allah Swt. Dan diampuni segala dosa serta diterima amal ibadahnya.

Selain itu Di Desa Rasau Jaya 1 orang jawa yang menjadi transmigran tetap menghidupkan kebudayaannya dibidang kesenian. Mereka memiliki kelompok kesenian jawa seperti wayang orang, ludruk, ketoprak dan pencak silat. Adapun upaya adaptasi masyarakat transmigran dengan penduduk asli adalah dengan membawa kesenian dari jawa dan dimainkan oleh masyarakat transmigran seperti reog, dan kuda lumping. Semua peralatan kesenian dimiliki oleh para transmigran, walaupun peralatan tersebut tidak lengkap. Pada saat itu selain terdapat berbagai kesenian Desa Rasau Jaya 1 memiliki tradisi sedekah bumi. Tradisi sedekah bumi merupakan tradisi rutin di Rasau Jaya 1 yang dilaksanakan satu tahun sekali, biasanya dilaksanakan pada akhir tahun dan bertempat di Balai Desa. Tradisi sedekah bumi dilaksanakan selama dua hari, dimulai dari pemasangan tenda hingga menuju pada acara puncak. Acara ini diikuti oleh seluruh masyarakat transmigrasi yang diisi dengan pengajian dan doa bersama untuk memberikan ungkapan rasa bersyukur atas hasil panen padi yang didapat selama satu tahun. Setelah acara selesai dilanjutkan dengan acara hiburan berupa wayang orang. Namun dengan semakin berkembangnya zaman tradisi ini mulai menghilang dan sudah tidak pernah dilakukan lagi pada saat ini. Lambat laun pun penduduk asli mulai ikut mempelajari budaya adat jawa dan mempelajari kesenian jawa karena kesenian jawa lebih dominan daripada kesenian penduduk asli yang 
kurang diketahui juga oleh masyarakat lainnya. Atas dasar adanya kesesuaian dan pembauran pergaulan secara membaur antara transmigran dan penduduk asli, kehidupan transmigran di Desa Rasau Jaya 1 terjalin secara harmonis. Begitu pula dengan naiknya taraf kesejahteraan keluarga transmigran yang meningkat seiring keseriusan mereka ditanah perantauan. Selain itu terdapat juga budaya yang dibawa oleh masyarakat transmigran ke daerah rasau jaya yaitu kesenian Kuda Lumping. Kuda lumping ini merupakan sarana hiburan masyarakat pada saaat itu yang masih kekurangan hiburan. Serta untuk melestarikan kebudayaan Jawa di lingkungan masyarakat Transmigran dan mengenalkan kesenian kuda lumping kepada penduduk asli di Rasau Jaya.

Kuda Lumping yang berdiri pertama kali yaitu Mekar Sari yang pada saaat itu masih menggunakan alat seadanya dengan kuda lumpingnya menggunakan pelepah pisang. Kuda Lumping ini dipimpin oleh Nursari dan beberapa temannya. Dengan seiring perkembangan zaman kuda lumping ini mulai memiliki peralatan yang memadai dan mulai dikenal oleh masyarakat baik di Rasau Jaya maupun luar Kecamatan Rasau Jaya. Tarian dari kuda lumping mekar sari ini juga masih tarian dari zaman dulu tidak seperti kuda lumping lainnya yang sudah banyak di modifikasi. Berbagai panggilan pun mulai berdatangan baik itu acara pernikahan, khitanan dan acara umum lainnya. Penikmat dari kesenian kuda lumping ini tidak hanya dari golongan tua saja, tetapi banyak anak muda yang antusias dalam setiap ada pegelaran kesenian kuda lumping. Hingga pada saat ini sanggar kesenian kuda lumping ini masih bertahan dan masih mampu bersaing dengan sanggar seni kuda lumping yang ada di Kubu Raya maupun diluar Kubu Raya. Hal yang penting dari masih bertahannya kesenian kuda lumping ini yaitu dengan adanya manajemen yang baik dari pihak pengelola. Dengan perkembangan zaman yang terjadi pada saat ini kesenian seperti kuda lumping sudah mulai jarang ditemui.

Selain kuda lumping, masyarakat Jawa di Rasau Jaya juga mengenal kesenian ludruk. Ludruk biasanya bercerita tentang kisah perjuangan ataupun cerita kehidupan sehari-hari. Keseniannya biasanya dilakukan pada malam hari sebagai hiburan masyarakat desa. Selain itu ada juga ketoprak, atau sandiwara tradisional yang biasanya menceritakan cerita-cerita lama. Kedua kesenian ini 
dalam pertunjukkannya diiringi dengan gamelan sebagai alat musik. Dalam pertunjukkan kesenian ini hubungan antara masyrakat transmigran dan penduduk asli akan berjalan dengan baik. Mereka yang menonton tidak hanya masyarakat trans saja namun penduduk asli juga ikut menonton sehingga terjalin komunikasi yang baik. Tentunya hal ini membuat proses adaptasi masyarakat transmigrasi di Rasau Jaya akan semakin baik karena sudah semakin berbaur dengan penduduk asli.

\section{SIMPULAN}

Pemukiman transmigrasi Rasau Jaya I dimulai pada tahun 1971-1974, terbentuk sebagai bagian dari program transmigrasi dari pemerintah pusat dan digolongkan sebagai jenis transmigrasi umum. Daerah transmigran sendiri berasal dari Jawa Timur, Jawa Tengah, dan Yogyakarta. Adaptasi para transmigran dengan lingkungan alam mereka dapat bercocok tanam yang mengikuti bercocok tanam penduduk asli yaitu dengan cara menebang pohon terlebih dahulu kemudian setelah itu mereka membakar lahan yang sudah dibersihkan. Para transmigran mampu beradaptasi sehingga mereka mampu untuk tetap bertahan ditempat transmigran sampai saat ini. Mereka mampu berbaur dengan penduduk asli di Desa Rasau Jaya 1 dan hubungan mereka terjalin harmonis. Begitu pula dengan naiknya taraf kesejahteraan para keluarga transmigran yang meningkat seiring dengan keseriusan mereka untuk tetap tinggal di tanah rantau. Masyarakat transmigran banyak mengenalkan berbagai budaya dan adat istiadat mereka di Jawa sehingga penduduk asli juga banyak yang ingin belajar dan mengetahui tentang kebudayaan Jawa. Sehingga akhirnya kebudayaan Jawa dan penduduk asli yang umumnya suku melayu saling menyatu dan berkolaborasi. Keberhasilan masyarakat transmigrasi di Rasau Jaya sendiri tidak terlepas dari bantuan penduduk asli mulai dari mengenalkan cara bercocok tanam yang benar pada tanah Kalimantan yang umunya adalah tanah gambut. Dengan akhirnya hal ini dapat memperkokoh kebhinekaan sesama suku bangsa di Indonesia.

\section{DAFTAR PUSTAKA}


MASA: Journal of History, Vol. 1, No. 2, Desember 2019

Kartodirdjo, Sartono.2019. Pendekatan Ilmu Sosial Dalam Metodologi Sejarah. Yogyakarta: Ombak.

Nurcahyani, Lisyawati \& Juniar Purba.2018. Integrasi sosial masyarakat transmigrasi Jawa. Yogyakarta: Diva Press.

Priyambodo.1989. Potensi rawa dan irigasi menunjang pengembangan transmigrasi di propinsi Kalimantan Barat.Pontianak: Departemen Imigrasi.

Priyadi, Sugeng.2012. Metode Penelitian Pendidikan Sejarah. Yogyakarta: Ombak.

Septiyani, Dewi. 2014. Para Transmigran di Desa Rasau Jaya 1 Kabupaten Kubu Raya Kalimantan Barat. Jurnal of Indonesian History (ISSN: 2252-6633), Volume 3, Nomor 1, halaman 10-14.

Swasono Sri Edi dan Masri Singarimbun. 1986. Transmigrasi di Indonesia 19051985. Jakarta: Universitas Indonesia. 